Monika KARBOWSKA

Université Paris 1 Sorbonne

\title{
Dlaczego Francuzi odrzucili Europejski Traktat Konstytucyjny?
}

\begin{abstract}
29 maja 2005 naród francuski odrzucił Europejski Traktat Konstytucyjny 2 większością 54\% głosów podczas referendum, którego frekwencja przekraczała $60 \%$ uprawnionych do głosowania. Ten historyczny moment wstrząsnął elitami politycznymi Unii Europejskiej i zdumiał inne narody. Zaskoczenie pochodzi stąd, iż polityka europejska bardzo rzadko poddana jest konsultacjom demokratycznym, i to od 50 lat, odkąd istnieją pierwsze wspólne instytucje. Do 2005 roku budowa Unii Europejskiej była wyłącznie zajęciem elit. Czasem elity wyrażały żal, że lud nie rozumie doniosłego znaczenia europejskich przemian. Tak więc 29 maja 2005 r. było wielkim wydarzeniem: naród wkroczył na scenę Unii Europejskiej i wypowiedział swoją opinię. Także Holendrzy dołączyli się do tej krytyki. Może i więcej narodów przyłączyłoby się do nich, ale po 29 maja ostrożne elity zatrzymały organizację referendów.

A miało być tak prosto: Konwent, któremu przewodniczył były francuski prezydent Valéry Giscard d'Estaing zgromadził na konsultacje kilkudziesięciu ekspertów ze wszystkich krajów Unii, dodał polityków i byłych polityków, profesorów prawa, różnych lobbystów z dziedziny gospodarki, nie zapomniał o kościołach i zapewnił sobie alibi demokratyczne w postaci kilku zaproszonych związkowców i przedstawicieli stowarzyszeń. Elity te opracowały w półtora roku Traktat Konstytucyjny szybko zaaprobowany przez Komisję Europejską i podpisany przez rządy państw Unii. Proces ratyfikacyjny poszedł w ruch, najpierw poprzez parlamentarzystów głosujących masowo za traktatem (francuski parlament ratyfikował traktat większością 90\% głosów!), a następnie poprzez pierwsze, zdawałoby się łatwo wygrane, referendum w Hiszpanii. Aż nagle elity trafiły na opór Francuzów.
\end{abstract}

\section{Krytyka tekstu Traktatu}

Krytyka społeczeństwa konkurencyjnego

Krytyka dotyczyła głównie artykułów mówiących o ,wolnej i nieskrępowanej konkurencji” jako celu Unii oraz nadrzędnej roli ,wol- 
ności przepływu kapitału” nad prawami człowieka. Wszystkie bardzo liczne w tak obszernym tekście artykuły ustanawiające kapitalizm ultraliberalny jako ustrój polityczny, społeczny i gospodarczy zostały poddane surowej krytyce. Mawiano, że taką konstytucję można porównać do konstytucji typu „sowieckiego" ponieważ ustala ona raz na zawsze ustrój gospodarczy, jaki ma panować w państwie i to w sposób tak ostateczny, że nigdy nie będzie można go zmienić. W tej argumentacji krytykowano artykuły I-3, I-4, oraz całą część III mówiącą o konkurencji jako jedynym sposobie organizacji życia gospodarczego i społecznego. Dla porównania konstytucje francuskie (siedem przeszłych oraz obecnie obowiązująca) nie mówią nic o ustroju gospodarczym: wystarczy, że zagwarantowana jest własność prywatna, którą jednak władza może uspołecznić dla celów publicznych za odszkodowaniem.

Jeśli chodzi o instytucje unijne, na fali dyskusji o Traktacie po raz pierwszy zaczęto krytykować obecny porządek europejski: słabość Parlamentu Europejskiego, jego brak inicjatywy ustawodawczej, która jest przecież podstawową prerogatywą suwerenności ludu, koncentrację władzy w rękach instancji niekontrolowanych demokratycznie (Komisja Europejska) lub reprezentujących obywateli w sposób pośredni poprzez władzę wykonawczą (Rada Europejska składająca się z szefów państw lub rządów). Traktat Konstytucyjny zapewniał wprawdzie trochę więcej władzy parlamentowi, ale inicjatywa ustawodawcza pozostawała przy Komisji co jest nieznośną herezją w kraju Monteskiusza. Trójpodział władzy pozostaje nadal dla Francuzów gwarancją demokracji. Nie krytykowano wprowadzenia stanowiska ministra spraw zagranicznych Unii, ani nowej organizacji prezydentury, ale fakt, że te instancje nadal nie byłyby kontrolowane demokratycznie, wzbudził duże obawy.

Unia Europejska zaczęła się jawić nagle jako dyktatura Komisji, urzędników mianowanych przez władze wykonawcze bez kontroli parlamentów narodowych i poddanych wpływom lobbystów wszelkiej maści, wśród których królują bogate międzynarodowe koncerny. Ludzie spotkani na zebraniach publicznych mówili nawet, że Unia kpi z nich, przedstawiając prawo do petycji (I-47) jako wielki skok w kierunku demokracji. Przecież petycje istnieją od czasów Ancien Regime'u i wszyscy wiedza, że nie jest to świadectwo demokracji, gdyż w petycji się prosi, a władca decyduje co chce zrobić z tą prośbą. Ponadto artykuł ten mówił wyraźnie, że petycja może mieć tylko za cel wcielenie w życie owej Konstytucji. Tak więc żaden obywatel, który nie zgadzałby się z Konstytucją, nie mógłby wpłynąć na zmianę ustawy z niej wypływającej za pomocą petycji. 


\section{Karta Praw Fundamentalnych}

Z totalnym odrzuceniem spotkała się część II - Karta Praw Fundamentalnych. Tekst ten opracowany został wprawdzie przez europejskie związki zawodowe na fali żądań „Europy socjalnej” po scysjach nicejskich 2000 roku. Ale Konwent Giscarda zaostrzył go tak w kierunku liberalnym, że nawet Konfederacja Europejskich Związków Zawodowych, pomimo, iż zgadzała się z Traktatem, nie rozpoznała w Traktacie tekstu, który negocjowała i musiała zaprotestować.

Francuzi po prostu śmiali się z tej Karty, która stanowiła dla nich kata$\log$ pobożnych życzeń typowych dla „ideologii antydyskryminacyjnej” ale nie zapewniała takich samych praw jak Konstytucja Francuska czy Uniwersalna Deklaracja Praw Człowieka z 1948 roku. Teksty te zapewniają bowiem prawo do pracy, do odpoczynku, do ubezpieczenia na wypadek bezrobocia czy choroby, zapewniają emerytury i renty, prawo do mieszkania, do kultury... Traktat nic z tego nie przewidywał a prawo do pracy zamieniło się $w$,prawo do szukania pracy i wykonywania zawodu oraz świadczenia usług" (Art. II 75). Nieustanowiono także ograniczenia czasu pracy, a prawo do nauki zamieniło się w artykule II-74 na „możliwość pobierania nauki”. Nigdzie też w Traktacie nie było napisane, że edukacja publiczna jest bezpłatna, a to właśnie jest dla Francuzów podstawowym prawem demokratycznym.

Prawo do strajku zostało zagwarantowane tak dla pracowników, jak i dla pracodawców, co odczytano we Francji jako jawną zachętę do lock-out'u. Ochronę przed zwolnieniem z pracy ograniczono tak bardzo, że praktycznie całe francuskie prawo pracy byłoby zagrożone postanowieniami Traktatu. Przykłady można by mnożyć... I zakończyć tym, że Traktat sam odbierał tym prawom wszelkie znaczenie prawne, gdyż artykuł II-111 mówił, iż „Karta nie nakłada na Unię żadnych nowych zobowiązań ani nie poszerza kompetencji Unii”. Gwarancje, które władze do niczego nie zobowiązują? Francuzi uznali to za kpinę i porównywali ironicznie tę Kartę praw do Karty nadanej im przez Ludwika XVIII w 1816 r. w czasie restauracji monarchii po Rewolucji... Taka „Karta Praw” jawi się więc jako monarszy gest, a jedynie Konstytucja stanowi prawdziwie demokratyczną gwarancję praw obywatelskich. Rzeczywiście, na tle ważkich słów Deklaracji Praw Człowieka i Obywatela z 1789 r., Konstytucja Europejska wyglądała jak spadłe z księżyca ufo... Nie mówiąc o tym, że Konstytucja nie może być traktatem przygotowywanym w zaciszu ministerialnych gabinetów. Konstytucję przygotowuje Konstytuanta złożona 
z wybranych przez naród przedstawicieli, którym naród powierza tak ważną misję. Liczne były w czasie kampanii głosy na rzecz powołania takiej europejskiej konstytuanty.

\section{Polityka społeczna i usługi publiczne}

Spora część krytycznych argumentów odnosiła się do polityki społecznej Unii oraz problemu usług publicznych. Cała część trzecia traktatu poświęcona była organizacji życia społecznego i gospodarczego Unii wokół naczelnej zasady rynku. Gdyby Traktat wszedł w życie, wszelka dzialalność ludzka zostałaby poddana zasadom rynku, a państwa Unii nie miałyby prawa prowadzić interwencyjnej polityki wspierającej przemysł, usługi ani nawet rolnictwo. Musiałyby zostawić wolną rękę rynkowi (III-178). Przedsiębiorstwa państwowe nazywane po francusku ,usługami społecznymi - service public", a obejmujące we Francji wielkie, rentowne i prężne firmy jak Elektryczność i Gaz Francji, Pocztę, Koleje (w tym najwyższej jakości w Europie szybkie linie TGV), nie występowały w Traktacie jako podmioty prawne. Widniało tam tylko pojęcie „firm wykonujących usługi ekonomiczne o znaczeniu ogólnospołecznym”. Naród francuski, lewica ale też spora część prawicy, sprzeciwia się prywatyzacji tak ważnych firm jak francuskie firmy państwowe. Obawiał się więc, że Traktat przypieczętuje ich los.

W artykułach III-203 rynek miał rozwiązać sprawę zatrudnienia. Słowo „bezrobocie” nie pojawia się zresztą w ogóle w Traktacie Konstytucyjnym, podczas gdy Unia liczy oficjalnie 20 milionów bezrobotnych. Celem polityki zatrudnienia jest dostosowanie siły roboczej do rynku, aby zrealizować cele Unii wyliczone w artykule VI-3, czyli „konkurencję wolną i nieskrępowaną". Nie było więc w Traktacie nic o walce $\mathrm{z}$ bezrobociem, gdyż bezrobocie po prostu nie istnieje jako problem dla Unii Europejskiej. W dodatku artykuł III-209 powtarzał jeszcze, że polityka socjalna Unii wyniknie samoistnie z „ewolucji rynku wewnętrznego”. Jeśli dodamy do tego przepis zabraniający państwom wspierania jakichkolwiek działań, które Traktat uzna za wchodzące w skład rynku, a Traktat nie wyjmuje nic spod działań rynku ani nauki, ani kultury, ani zdrowia... wszystko mogłoby więc zostać sprywatyzowane. Nawet jakakolwiek polityka regionalna stałaby się wówczas niemożliwa. Niebezpieczeństwo to zostało szybko dostrzeżone przez obywateli francuskich mających jakiekolwiek, nawet skromne, funkcje społeczne: radnych miejskich i wiejskich, dzia- 
łaczy milionów stowarzyszeń społecznych, edukacyjnych, sportowych, ekologicznych, nauczycieli, lekarzy... Każdy mógł poczuć się zagrożony tak ultraliberalnym przepisem.

\section{Polityka obronna}

Pomimo, iż Traktat uznawał „definicję europejskiej polityki obronnej” (I-41), za skandal uznali Francuzi wpisanie w Konstytucję Europejską zapewnienia, że „NATO jest podstawą polityki obronnej i instancją wykonawczą tej polityki" w artykule I-42.7. Nawet prawica francuska jest zdania, że NATO, dowodzone i założone przez Stany Zjednoczone, nie jest instytucją europejską, a wpisanie jej w Traktat przypieczętuje rezygnację z wszelkiej polityki europejskiej niezależnej od USA. Zarówno lewica, jak i prawica podkreślały, że gdyby Traktat obowiązywał w 2003 roku, trudno byłoby rządowi francuskiemu przeciwstawić się wojnie w Iraku. Francja należy wprawdzie do NATO, ale uważa, że przynależność ta nie jest sprzeczna z prowadzeniem samodzielnej polityki europejskiej i światowej, albowiem NATO zostało założone jedynie przeciw ZSRR i tylko w takim celu miało być wykorzystane. Wielu Francuzów uznaje rozwiązanie NATO za pożądany cel, skoro instytucja ta wypełniła już swoje zadanie. Lewica krytykowała także Traktat za to, że w dobie nowego wyścigu zbrojeń i nowych wojen nie mówił on nic o rozbrojeniu, o dążeniu do pokoju czy o międzynarodowej współpracy w celu rozwiązywania napięć między państwami.

\section{Prawa kobiet i laickość}

Europejski Traktat Konstytucyjny wymieniał wprawdzie równość mężczyzn i kobiet jako ostatnią z wartości Unii (I-2) oraz jako cel Unii (I-3), ale właściwie poza tym ogólnikiem nie było w nim nic o prawach kobiet i ta nieobecność została dostrzeżona. Przemilczenia Traktatu mogłyby potencjalnie doprowadzić do decyzji politycznych fatalnych dla kobiet. Nie było $w$ Traktacie nic o prawie do antykoncepcji i do aborcji zakazanej w 4 krajach Unii (Irlandia, Portugalia, Malta i Polska), a prawa te są uważane tak przez działaczki feministyczne, jak i przez miliony Europejek za podstawowe prawa do stanowienia o sobie. Dodajmy do tego klauzulę akcesyjną Malty, która wchodziła w skład Traktatu i w której czarno na 
białym napisane było, iż Unia po wsze czasy zobowiązuje się szanować obowiązujący na Malcie zakaz przerywania ciąży. Tymczasem kilkaset kilometrów na północ od Malty, we Włoszech czy Francji, aborcja jest uznana za niezbywalne prawo i jako takie wspierana przez Unię w ramach polityki równości płci... Gdy to widzimy rozumiemy łatwo jak bardzo podwójna moralność i cynizm Unii rozsierdziły czytelników Traktatu. Polska także podpisała podobną klauzulę akcesyjna, tyle tylko, że nie widniała ona w Traktacie.

Krytykę wzbudził także artykuł II-69 stanowiący prawo do małżeństwa i zakładania rodziny, podczas gdy przemilczano prawo do rozwodu zakazanego przecież na Malcie. Natomiast orientacja seksualna, prawo do życia poza małżeństwem widocznie w ogóle nie wchodziło w grę jako sposób na życie wspierany na równi z tradycyjną rodziną. Traktat nie wydawał się przynosić nic postępowego w tej kwestii, a mógł nawet zagrozić istniejącym we Francji rozwiązaniom prawnym. Traktat nie przewidywał też małżeństwa cywilnego, co w kontekście ślubów konkordatowych forsowanych przez Watykan albo muzułmańskich ślubów zwyczajowych powszechnych w Belgii czy Holandii nie zabezpiecza na dłuższą metę praw kobiet. Bowiem kobiety są pierwszą ofiarą propagandy antyrozwodowej, antyaborcyjnej i antyseksualnej, którą Watykan rozwija poprzez obowiązkowe przed ślubem konkordatowym mizoginiczne nauki przedmałżeńskie. Brak zabezpieczenia na poziomie europejskim instytucji małżeństwa i rozwodu cywilnego może też doprowadzić do uznania dyskryminujących kobiety zwyczajowych ślubów muzułmańskich, brakiem prawa do rozwodu dla kobiety i uznaniem mężczyzny za głowę rodziny. Do tego zmierzają powoli ale skutecznie islamskie stowarzyszenia działające w Anglii, Belgii, Holandii i Niemczech.

Artykuł I-52 obiecujący, że Unia uznaje zastany porządek religijny każdego państwa, a nawet będzie ,prowadzić dialog otwarty, regularny i jawny z kościołami” stał się symbolem podeptania przez Unię nieodlącznej dla Francuzów od demokracji zasady świeckości państwa. „Republika nie uznaje i nie utrzymuje żadnego wyznania” - to są pierwsze słowa Ustawy o Rozdziale Kościołów od Państwa z 1905 roku zdobytej po wielu latach walk. W 2005 roku Republika Francuska obchodziła stulecie tej podstawowej dla życia społecznego zasady. Bez niej nie ma republiki rozumianej jako demokracja. Laickość państwa czyni to co wspólne ważniejsze od tego co dzieli, gdyż ogranicza religię i związane z nią wierzenia do sfery osobistej. Dzięki temu rozwiązaniu nie tylko różne religie mogą spokojnie koegzystować, ale także stworzona zostaje wspólna 
płaszczyzna, na której można budować społeczeństwo równych. Bez tej zasady nie ma świeckiej szkoły, nie byłoby powszechnej opieki społecznej, ani prawa do aborcji i do antykoncepcji. Ustanowienie konstytucyjnego dialogu z Kościołem Francuzi uznali za obelgę. I cóż Unia chciała dać w zamian? Zasadę „uznania stowarzyszeń filozoficznych”. Unia je uznaje ale nie gwarantuje, że będzie z nimi rozmawiać na równi z kościołami!

W dobie olbrzymich wpływów fundamentalistów tak islamskich, jak katolickich w Unii (konkordaty, powrót katechizmów do szkół, zamachy na prawo do aborcji, wymuszone śluby, propaganda przeciw prawu do wolnej seksualności kobiet, masowe naciski przeciw emancypacji kobiet muzułmańskich...) cynizm Unii w sprawie „dialogu religijnego" uznany został za patologiczny. Dla Francuzów świadomych tej sytuacji we Francji i w Europie dialog z kościołami - bez ich rozdziału od państwa jest nie do przyjęcia. Nie chodzi tu tylko o kwestię symboli islamskich takich jak osławiona chusta w szkołach, ale także o propagandę jaką islamiści szerzą przeciw świeckiej szkole, w której młodzież czyta ateistę Woltera czy pobiera naukę o świadomej i odpowiedzialnej seksualności. Dodajmy do tego artykuł II-70 zapewniający swobodę „manifestowania swojej religii tak publicznie jak prywatnie" i już świeckość publicznej szkoły francuskiej jest zagrożona. Publiczna szkoła jest miejscem, gdzie na mocy rozdziału kościołów od państwa, struktury i symbole religijne nie mogą egzystować. Artykuł ten odebrałby tym zasadom całą moc prawną.

\section{Kampania}

Krytykowano powszechnie zbyt długi tekst traktatu napisanego językiem tak trudnym, że nawet ludzie z wyższym wykształceniem mieli trudności ze zrozumieniem co za niespodzianki szykuje im Unia Europejska. Dla Francuzów Konstytucja ma być krótka, jasna, przejrzysta oraz napisana językiem dostępnym tak, aby każdy obywatel, nawet niewykształcony, mógł przeczytać w niej swoje prawa i obowiązki, gdyż znajomość własnych praw jest podstawą demokracji.

Kampania była barwna i różnorodna, prowadzona przez setki tysięcy obywateli - przez partie polityczne, stowarzyszenia, związki zawodowe oraz przez indywidualnych, niezrzeszonych obywateli. Tysiące osób pisało teksty, gazetki, strony internetowe i ulotki, rozprowadzano je na ulicy, na zebraniach publicznych i wśród znajomych. Olbrzymie znaczenie dla początku kampanii miał apel Fundacji Kopernika zwany „Apelem 200-stu”. 
Fundacja Kopernika jest stowarzyszeniem lewicowych naukowców, którzy wyznaczyli sobie za zadanie analizę negatywnych zjawisk ultraliberalnej globalizacji i udostępnienie ich publiczności, tak by działacze polityczni lewicy mieli argumenty oparte na solidnych naukowych podstawach. Analiza Traktatu, którą opublikowała Fundacja Kopernika, była bezwzględnie negatywna. Fundacja nawoływała więc do głosowania NIE w referendum. Apel Fundacji znalazł się na wielu alterglobalistycznych stronach internetowych już w połowie 2004 roku.

Analizy te rozpropagowało także silne alterglobalistyczne stowarzyszenie ATTAC Francja, w skład którego wchodzi wielu naukowców czynnych w Fundacji Kopernika, zwłaszcza ekonomistów lewicowych - przeciwników ekonomii neoliberalnej. ATTAC przeprowadziło wewnętrzne referendum i większość 20000 tysięcy członków wypowiedziało się przeciw Traktatowi. Wtedy ATTAC rzucił w wir kampanii wszystkie swe intelektualne i polityczne siły. Wydrukowano dwie książki zawierające niezwykle precyzyjną analizę nie tylko Traktatu, ale wszystkich liberalnych polityk europejskich prowadzonych od powstania Europejskiej Wspólnoty Gospodarczej w powiązaniu z polityką Banku Światowego, Międzynarodowego Funduszu Walutowego oraz Światowej Organizacji Handlu. Książki te, o niskiej cenie i napisane przystępnym językiem, pokazywały obywatelowi jakie są kulisy „reform”, które pogarszają poziom jego codziennego życia tak materialnego, jak etycznego i jakie są powiązania międzynarodowych elit ultraliberalnych z polityką Unii. Dzięki tym publikacjom przeciętny obywatel miał zrozumieć „co na niego szykują” zanim podejmie decyzję. Dla stowarzyszenia ATTAC wiedza jest podstawą demokracji, a zadaniem stowarzyszenia jest szerzyć tę wiedzę.

W tym samym czasie powstało w całym kraju ponad 600 komitetów zrzeszających lokalnych działaczy lewicowych i centro-lewicowych partii politycznych, związków zawodowych, stowarzyszeń. W całym kraju, przez 9 miesięcy kampanii, od września 2004 roku do 29 maja 2005 codziennie w tysiącach wsi, dzielnic miast i miasteczek odbywały się publiczne dyskusje i wiece. Prelegentami byli lokalni działacze, a centralny sekretariat mailowo organizował przyjazdy znanych na cały kraj działaczy politycznych i społecznych. Zebrania te często organizowały kobiety. Ludzie czytali Konstytucję, zaznaczali szokujące lub niezrozumiałe fragmenty i przychodzili na zebrania z pytaniami i Traktatem w ręku. Żarliwe dyskusje dzieliły „nonistów” („tych co mówią nie”) od „ouistów” (,takowców”). Okazywało się też często, że podział na „Nie” i „Tak” nie był podziałem na różne opcje polityczne, ale był miernikiem pozycji 
społecznej. „Noniści” byli na ogół poza systemem liberalnym, wykluczeni lub w trakcie bycia wykluczonymi, „ouiści” byli w systemie, przeważnie członkami elity albo klas średnich jeszcze nie dotkniętych przez pauperyzację. Na tle tej kampanii było zresztą najlepiej widać deklasację klasy średniej zagrożonej coraz bardziej dzikim kapitalizmem. W publicznych dyskusjach ekonomiści z uniwersytetów thumaczyli związki między delokalizacjami, czyli przenoszeniem fabryk do krajów o taniej sile roboczej, w tym do Polski, a polityką Unii, podczas gdy na sali odzywały się głosy robotników ofiar tychże delokalizacji. Robotnicy mówili własnymi słowami o tych samych sprawach co ekonomiści. Przez moment czuliśmy społeczeństwo jako żywy organ złożony z więzi ludzkich i czuliśmy, że te więzi są możliwe.

Bardzo dużą rolę odegrał Internet: do legendy przeszła historia Etienne'a Chouard'a, zwykłego prowincjonalnego nauczyciela prawa i ekonomii, który najpierw chciał głosować „tak” nieprzeczytawszy Konstytucji. Ale napotkał krytyczną ulotkę i zabrał się za wnikliwą lekturę tekstu. To co ujrzał było tak szokujące dla jego republikańskich przekonań, że założył stronę internetową, która odegrała potem olbrzymią rolę w kampanii. Codziennie wyjaśniał znaczenie poszczególnych artykułów tekstu i ich potencjalny wpływ na życie szarego człowieka oraz dyskutował na swoim forum. Etienne Chouard stał się w końcu sławny, był zapraszany na liczne debaty ciągle nie będąc członkiem żadnego ugrupowania politycznego. Nawet liberalna, masowo „takowska” prasa musiała zdać relacje o nowym zjawisku demokratycznym. Fora i listy dyskusyjne wysyłały tysiące analiz, ulotek i opinii. Partie polityczne i wszelkie ruchy społeczne, nawet czasem oddalone od polityki, publikowały własne analizy, w Internecie czy na papierze. Dyskusja polityczna zataczała coraz to szersze kręgi i obejmowała coraz to nowe tematy. Wspomnieć można takie publikacje jak strona internetowa, której twórca umieścił teksty wszystkich konstytucji Francji od 1791 począwszy i nie krył się z tym, że jego ulubioną jest Konstytucja z 1793 roku! Kampania była także przyśpieszoną lekcją historii. Obok Internetu interesującą rolę odegrało kino. Np. dokumentalny film L'Europe mal traitée (Europa źle potraktowana) nakręcony przez dwie zupełnie nieznane działaczki społeczne stał się szlagierem kampanii. Pokazywano go w całej Francji, sale były przepełnione a dyskusja publiczna po filmie zamieniała się w ostrą krytykę całego systemu. A film nie pokazywał nic innego jak tylko rozmowy z ekonomistami krytykującymi Traktat oraz dyskusje z ludźmi na ulicy na temat ich własnej sytuacji społecznej i ekonomicznej. 
Wspomnieć należy też o inicjatywach zrodzonych z Europejskiego Forum Społecznego, którego trzecie wydanie miało miejsce w Londynie w październiku 2004 roku tuż przed rozpoczęciem francuskiej kampanii. Europejska Inicjatywa Feministyczna, sieć kilku tysięcy europejskich feministek założona na Europejskim Forum Społecznym w Paryżu w 2003 roku, skorzystała z Forum w Londynie by uchwalić uroczyście Manifest krytykujący Traktat z punktu widzenia feministycznego. Była to pierwsza ściśle europejska krytyka Traktatu rozpoczęta przez te działaczki już w poprzednim roku. 8 lutego 2005 r. manifest został opublikowany we Francji i stanowił dobrą podstawę krytyki Traktatu z pozycji interesów kobiet europejskich.

Wbrew temu co krzyczała liberalna prasa o izolacji Francji, liczni działacze z innych krajów Europy przyjeżdżali do Francji udzielić wsparcia z krajów, w których pozbawiono ludzi debaty publicznej, ratyfikując traktat w Parlamentach albo manipulując opinią publiczną. Hiszpania była najlepszym przykładem manipulacji opinii publicznej, bowiem Traktat był tam dostępny jedynie w trzech punktach sprzedaży w całym kraju tak, że ludzie głosowali nie znając wcale tekstu traktatu.

Manipulacja tego typu miała się odbyć także we Francji, gdzie rząd przygotował jedynie propagandową książeczkę popierającą Traktat, a sam tekst był dostępny na początku jedynie w Internecie w wersji 200-stu stronicowej. Wtedy komunistyczny dziennik „L'Humanité” opublikował w całości tekst Traktatu w październiku 2004 roku. W ciągu kilku miesięcy publikacja stała się bestsellerem. Dopiero gdy sondaże pokazały, że NIE może zwyciężyć, rząd udostępnił traktat w każdym domu na dwa miesiące przed głosowaniem. Kwestia wolności słowa stała się zresztą paląca, bowiem całość mediów należących czy to do koncernów prywatnych, czy będących własnością publicznąjak państwowa telewizja, opowiedziało się za Traktatem i bez skrupułów prowadziło intensywną propagandę. Część dziennikarzy publicznych mediów, zmuszonych przez redakcje do propagowania TAK wbrew własnym opiniom, odpowiedziało strajkiem i manifestacjami protestującymi przeciwko tak nachalnej manipulacji.

Nawet ważniejsi działacze Partii Socjalistycznej wsparli NIE choć mogli za to być wykluczeni z partii. Wielu z nich było radnymi miejskimi $i$ to z punktu widzenia tej funkcji publicznej krytykowali traktat. Wskazywali na przykład, że uniemożliwi on im wspieranie działalności socjalnej, gdyż według zasad Traktatu wszędzie ma panować konkurencja, a władze publiczne nie będą mogły wybierać sposobu swojej interwencji. Solidar- 
ność nie jest jeszcze zupełnie pustym słowem we Francji i stąd pochodzi przywiązanie Francuzów do usług publicznych.

\section{Mój udział i rola Polski w kampanii}

Jako emigrantka poznałam z bliska mechanizmy dyskryminacyjne neoliberalnego państwa i społeczeństwa francuskiego. Długie lata znajdowałam się na najniższym miejscu hierarchii społecznej: ludzi „nielegalnych”, „bezpapierowców” lub półlegalnych, posiadających ograniczone prawo pobytu bez prawa do pełnej integracji, czyli do pracy. Na tym poziomie społecznym doświadczyłam brutalnych przemian ekonomicznych i społecznych, jakim poddane jest społeczeństwo francuskie od 15-tu lat nim obywatele francuscy zdążyli zorientować się co odbywa się w ich kraju.

Od wielu lat staram się opowiadać co stało się w Polsce od 1989 roku, bowiem we Francji panuje prawdziwe embargo na informacje dotyczące Europy Środkowo-Wschodniej. Na przykład na początku lat 90-tych nie było w prasie francuskiej żadnego artykułu dotyczącego zakazu aborcji w Polsce, ani żadnego artykułu o konkordacie, ani też nic o brutalności przemian kapitalistycznych. Polska przedstawiana jest jako dynamicznie rozwijający się kraj kapitalistyczny, gdzie kapitalizm jest rajem dla całego społeczeństwa, a to wszystko dzięki inwestorom zagranicznym oczywiście głównie francuskim. Nawet poziom bezrobocia nigdy nie jest podawany do wiadomości społeczeństwa francuskiego, tak aby publiczność myślała, zgodnie z zamierzeniami propagandystów, że „,nie ma odwrotu od kapitalizmu ultraliberalnego". Tym sposobem wszelka wiedza dotycząca Europy Wschodniej zanikła zupełnie nawet wśród ludzi wykształconych. Polacy będący na emigracji nie pomagają specjalnie francuskim znajomym w nabyciu rzetelnej wiedzy o sytuacji polskiej. Często bowiem potwierdzają oficjalną propagandę o „Polaku wiecznym katoliku” albo o kapitalizmie raju na ziemi, gdyż często wstydzą się prawdy o kraju albo brakuje im koncepcji intelektualnych by wyjaśnić co się tak naprawdę dzieje w Polsce od 1989 roku. Jeśli o mnie chodzi bardzo wiele nauczyłam się od działaczy ATTAC: dzięki ich publikacjom zrozumiałam, że te zmiany, które zmusiły mnie do opuszczenia kraju w 1992 roku są po prostu polską odmianą światowej globalizacji kapitalistycznej. Mogłam przemówić publicznie i kampania antykonstytucyjna była do tego znakomitą okazja.

Europejska Inicjatywa Feministyczna poprosiła mnie o krytykę Traktatu z punktu widzenia Europy Środkowo-Wschodniej. Znałam już Mani- 
fest Inicjatywy i zgadzałam się w pełni z jego założeniami. W lutym 2005 roku przestudiowałam Traktat i napisałam artykuł Dlaczego Traktat Konstytucyjny jest pułapka dla kobiet z Europy Środkowo-Wschodniej, który przedstawiłam na konferencji prasowej Inicjatywy w senacie francuskim 8 lutego 2005 r. Artykuł ten spotkał się z olbrzymim zainteresowaniem. Opublikowany został na niezliczonych stronach internetowych alternatywnych mediów, stowarzyszeń, partii oraz na stronach prywatnych i na listach dyskusyjnych. Siła Internetu zadziałała w pełni, gdyż kolejni czytelnicy polecali go dalszym czytelnikom, komentowali i prowadzili własne poszukiwania dotyczące tematu. Przy okazji ujawnili się inni polscy emigranci działający politycznie we francuskiej lewicy czasem nawet od dziesiątków lat. Spotkania z tymi ludźmi były pełne emocji, a więzi tak utworzone służą nam obecnie do dalszej działalności na forum europejskim i francusko-polskim. Po tych publikacjach zostałam zaproszona na prawie 20 wieców i spotkań w całej Francji, by wytłumaczyć ludziom moją krytykę Traktatu z punktu widzenia feminizmu i Europy Wschodniej.

Artykuł mój został też opublikowany w „L’Humanité” 28 lutego. Był to akurat dzień wizyty Aleksandra Kwaśniewskiego we Francji i spotkania z Jacques'iem Chirac'iem w Amiens, z okazji obchodów rocznicy II wojny światowej i udziału Polaków w wyzwoleniu Francji. Był to też okres, w którym stosunki polsko-francuskie podnosiły się z trudem po zapaści z powodu polskiego udziału w wojnie w Iraku. Bardzo się cieszę, że artykuł ten niewątpliwie został dostrzeżony przez władze polskie, dział prasowy ambasady ma bowiem obowiązek informowania centrali o tym co pisze prasa francuska o Polsce z okazji wizyty prezydenckiej. Niewątpliwie trafili także na mój artykuł w „L"Humanité”. A artykuł ten był radykalną krytyką polityki ostatnich 15 lat. Tłumaczyłam przywiązanie Polaków do demokracji odzyskanej pokojowo w 1989 roku, nadzieje $\mathrm{z}$ tamtego okresu związane w dużym upolitycznieniem społeczeństwa, które starało się w końcu wziąć swoje sprawy we własne ręce. Tłumaczyłam Plan Balcerowicza, manipulacyjne dojście do władzy przez Lecha Wałęsę, polski dług, otwarcie granic, likwidację przemysłu polskiego, spustoszenie ekonomiczne, społeczne i psychologiczne spowodowane zamknięciem przemysłu w wielu regionach, a potem jego częściową odbudowę przez koncerny zachodnie. Napisałam także obszernie o polityce Kościoła, jego ideologii mizoginistycznej i fundamentalistycznej, o wymuszonym konkordacie i o zakazie aborcji, przeciwko któremu walczyliśmy. Dodałam oficjalne liczby bezrobocia w Polsce (nawet te, przecież zaniżone, liczby budziły grozę wśród francuskich czytelników, którzy nie 
wyobrażali sobie jak społeczeństwo polskie może tak żyć) i wytłumaczyłam, że jest ono przyczyną trwającej już od początku lat 90-tych emigracji, emigracji którą dobrze znałam, gdyż wśród niej żyłam. Więzi między fundamentalizmem religijnym a kapitalizmem ultraliberalnym stały się jasne na przykładzie Polski. Dodałam, że nawet tak bardzo liberalna Konstytucja Europejska jest i tak postępem w porównaniu z sytuacją w Polsce, co tłumaczy dlaczego Polacy będą głosować za Traktatem.

Wówczas pojawiła się na wokandzie sprawa dyrektywy Bolkesteina. Działacze lewicowi we Francji bardzo szybko zidentyfikowali dyrektywę Bolkesteina wraz z ,zasadą kraju pochodzenia” jako niezwykle groźnego konia trojańskiego w prawie pracy krajów zachodnich. Jeśli zostanie wprowadzona zasada pierwszeństwa prawa pracy kraju pochodzenia pracownika, Europejczycy mogą pożegnać się z resztkami osłon socjalnych, gdyż olbrzymie bezrobocie w Polsce, potem Rumunii i gotowość ludzi do pracy za każdą cenę doprowadzi do totalnej erozji zachodniego prawa pracy. Poziom zarobków obniży się szybko, gdyż pracodawcy będą systematycznie wybierać tańszego pracownika. Rok po przegłosowaniu dyrektywy, nawet w złagodzonej pod presją społeczną formie, pokazuje nam, poprzez rzesze Polaków pracujących na Zachodzie na polskich umowach za 400 euro miesięcznie, że niestety mieliśmy racje. To Fritz Bolkestein wymyślił „polskiego hydraulika” w programie telewizji publicznej we Francji w marcu 2005 kiedy przyjechał bronić swojej ultraliberalnej ustawy. To hasło obróciło się przeciwko niemu, ponieważ nieustannie na wiecach i zebraniach, na jakie byłam zaproszona, w czasie kampanii opowiadałam moją historię i historię milionowej emigracji polskiej. Ludzie szybko zrozumieli, że dyrektywa Bolkesteina to legalizacja na najniższym poziomie zarobków wschodniej emigracji do krajów starej Unii. Podawałam jakie są w Polsce zarobki, jakie ceny, jakie bezrobocie w jakich regionach, a wszystko z oficjalnych statystyk. Ludzie słuchali mnie przerażeni. Nic o tym nie wiedzieli, ponieważ zetknęli się w mediach jedynie z propagandą sukcesu kapitalizmu w Polsce. Pojęli, że zasada dyrektywy, wpisana w Traktat, doprowadzi do masowej obniżki wynagrodzeń we Francji, i tak niewysokich, a w niczym nie pomoże Polakom. We Francji najniższa pensja zwana SMIC wynosi 1000 euro, a przy tym trzeba wydać średnio 500 euro na mieszkanie, 100 na transport, 50 na ubezpieczenia, tyleż za prąd i jeszcze za wodę... Średnia pensja wynosi 1350 euro, a od 1100 euro zalicza się przynależność do klasy średniej! Bezrobotnych jest 5 milionów, 4 miliony ludzi pracuje na umowach krótkoterminowych nie wiedząc z czego jutro będą żyli. Półtora miliona żyje z opieki społecznej 
opiewającej na 400 euro miesięcznie, gdy jest to wysokość średniego czynszu w najbiedniejszej dzielnicy. Wyliczono 7 milionów biednych mających poniżej 700 euro na życie dla dwóch osób... Obraz przyszłości Europy neoliberalnej, jaki wyłaniał się powoli z dyskusji nad Traktatem był przerażający. Ludzie obecni na zebraniach pojęli jak wielką mają odpowiedzialność idąc na głosowanie 29 maja.

Jeszcze większe przerażenie ogarniało Francuzów, gdy im mówiłam o potędze polskiego kościoła, o jego propagandzie przeciw „kulturze śmierci", o Radiu Maryja, o zakazie aborcji i konkordacie... Ogarniała ich także wściekłość, ponieważ media NIC nigdy o tym nie pisały i nie mówiły. A przecież wszystkie wielkie dzienniki francuskie posiadają korespondentów w Polsce, mają ścisłe kontakty z polską prasą, a nawet często należą do tych samych firm! Francuzi pojęli, że milczenie to nie jest przypadkiem, ale dezinformacją, że systemowi kapitalistycznemu zależy na tym by obywatel nic nie wiedział o postępach czarnosecińców i faszystów w Europie.

Na koniec muszę podkreślić, że polskie elity polityczne nie broniły wystarczająco w Konwencie Giscarda interesów Polski. Art. III 167 zakazuje bowiem państwom Unii pomagania i wspierania jakichkolwiek działań „fałszujących konkurencję” z wyjątkiem pomocy regionom Niemiec, które, jak to precyzuje tekst, „ucierpiały z powodu podziału Europy”. Jak powszechnie wiadomo, jedynie biedne Niemcy ucierpiały z podziału Europy. Tekst ten świadczy o tym, że Niemcy zadbali o własne interesy. A Polska? Czy polski rząd podpisując traktat w ogóle go wcześniej przeczytał?

\section{Zakończenie}

Dzięki tej kampanii znalazłam miejsce działania. Europejska Inicjatywa Feministyczna uczestniczyła w Europejskim Forum Społecznym w Atenach w maju 2006 roku, gdzie zorganizowała seminaria dotyczące sytuacji kobiet w Europie Wschodniej i seminarium o konieczności rozdziału kościoła od państwa w Europie. Na seminarium to zaprosiłam Czesława Janika, prezesa stowarzyszenia NEUTRUM. Owocem tej współpracy był cykl artykułów o Polsce w piśmie „Pro-Choix” oraz wizyta prof. Marii Szyszkowskiej na Uniwersytecie letnim ATTAC Francja. Inicjatywa opracowała także kwestionariusz przedstawiający wpływ struktur religijnych na życie społeczne i polityczne, w tym na sytuację kobiet, w każdym 
z krajów europejskich. Nawiązano kontakty ze stowarzyszeniami z Hiszpanii, Włoch, Grecji, krajów byłej Jugosławii, Rumunii, Bułgarii i Turcji. Kwestionariusze pokazują niepokojące, a nawet przerażające zjawiska w różnych krajach. Na ich podstawie zarysowuje się coraz bardziej konkretny polityczny program świeckiej Europy.

Jeśli chodzi o ratyfikację Traktatu, to zatrzymanie procesu referendów wydaje się tymczasowe. Nie jest wykluczone, że Unia Europejska będzie chciała zmusić Francuzów by głosowali powtórnie, dopóty dopóki „tak” nie zwycięży. Jeśli tak się stanie, należy liczyć się z ogromnym sprzeciwem, gdyż kraj ten, gdzie demokracja jest najstarsza na kontynencie europejskim, nie zniesie takiego dyktatu i sprzeniewierzenia się elementarnym zasadom demokracji. Referendum zastopowano także dlatego, że działacze na rzecz NIE, przygotowywali się do organizacji dyskusji i wieców w innych krajach europejskich, w których przewidziane było referendum, w tym i w Polsce. Nasze NIE mogło zapalić całą Europę. Nadzieja żyje nadal, kontynuujemy prace nad nową Europą socjalną, solidarną, ekologiczną, świecką i feministyczną.

październik 2006

\section{Summary}

The Author presents the main elements of the Euroconstitution that have caused the greatest protest of French society and resulted in its rejection in the referendum of May 2005. These include: the ultra-liberal economic system of the EU, poor protection of human rights and the rights of employees, poor security of democratic functioning of the EU structures, subjecting of the EU defense policy to NATO, failure to provide for a secular character of states and insufficient guarantees of women's rights. The second part of the paper is devoted to the analysis of the activity of French civic society in the constitutional campaign and to the Author's participation in this campaign. 